\title{
The Effectiveness of Split Dictation as A Teaching Strategy to Improve Students' Listening Skill
}

\author{
Tri Widi Kurniawan, C. Murni Wahyanti
}

English Department, Faculty of Languages and Arts, Universitas Negeri Semarang, Indonesia

\begin{tabular}{l} 
Article Info \\
\hline Article History: \\
Received in 27 November \\
2018 \\
Approved in 29 July \\
2019 \\
Published in 29 July \\
2019
\end{tabular}

Keywords: Split Dictation Technique; Listening Skill

\begin{abstract}
The objectives of this study are to find out whether or not split dictation technique is an effective technique to improve students' listening skill and to find out whether or not there is a significant difference between students who were taught by using split dictation and those who were taught by using a conventional method. This study is a quantitative research using quasy experimental as the method of collecting data. The subject of this research was 72 students of the tenth-grade students of SMA N 1 Sukorejo. In obtaining the data, the researcher conducted the pre-test, treatments, and the post-test. The results of this research showed that the mean score of the experimental group is 82,7 and the control group is 77,638 . By using IBM SPSS 23 th version program, the computation of t-test which the score of the sig ( 2 tailed) is (0.000) lower than (0.05), and the result of t-value (4.189) is higher than the t-table (1.994). In conclusion, there is a significant difference between the students' listening test achievement. The students who were taught by using split dictation has higher achievement, this indicated that split dictation is effective enough to improve students' listening achievement.
\end{abstract}

(C) 2019 Universitas Negeri Semarang

Correspondent Address:

ISSN 2252-6706

B3 Building FBS Unnes

Sekaran, Gunungpati, Semarang, 50229

E-mail: Kurniawanw1813@gmail.com@gmail.com 


\section{INTRODUCTION}

Listening is one of the most important areas to teach English learners. Every learner has to focus on their listening skill because listening is a process how to understand others. According to Nunan (2001, p.23) listening is the process of understanding, learners have to analyze the meaning of what they have heard and understand symbols they have seen and heard. How to understand language is through sound, that is why the listening should come first. The listening processes actually should come through, first they hear the sounds, second, they try to recognize the words they are listening as the input, and the third they can process the word in their brain to realize the meaning and understand the speaker means.

Based on the writer's observation in teaching practice last year, the writer found that so many students have difficulties in understanding the English language as their foreign language. When listening comprehension was taught in the class, students seemed still face difficulties in listening to auto media. It could be seen from the students' score in listening comprehension was still low than the teacher expected. As a result of this activity, some of the students seem difficult to answer the questions because the rate of conversation is fast enough, the speaker speaks unclearly. They accustom by their teachers' method, listening on recording and answering the question. Students seem to be bored because the recording material was given since they were at elementary school and they want something new and different.

Based on the statement above, the writer wants to use a different technique to improve the students' listening ability. Using dictation technique could be one of the ways to improve their listening skills in understanding English content. Dictation is a technique to decode or to translate sounds into written form. Davis and Rinvolucri (1998) claim that dictation contains a wealth of new techniques to extend the traditional language-learning activity. Kidd (1992) stated in his book entitled Teaching ESL Students through Dictation, dictation is interesting, motivating, communicative, and specifically designed for the teaching listening. Students performing split dictation exercises are generally required to transcribe the text as accurately as possible. In the previous studies (Sari, 2014), found that dictation can stimulate students' active participation and enhance students' listening ability. It proven by previous researchers such as (Kiany, 2012; Aini, 2015; Dwinalida, 2012), found that there is a significant improvement of the students' score after they are being treated by using dictation techniques.

In line with the explanation above the researcher chooses a dictation technique called split dictation technique. Kidd (1992) stated that one of the dictation techniques, split dictation can help students to diagnose and correct these kinds of errors as well as others, and the purpose of split dictation for the students is to practice listening skills and spelling skills. According to Kidd (1992, p.53) split dictation is often acts as a memorization exercise or a spelling-checking activity where teacher dictates a particular passage by splitting the students into two groups in the classroom. It is an activity where students reconstruct the text, combining the two "half-texts" they have written down to produce a complete version, it can increase their ability to notice aspects of the language while they are listening, and realize some mistakes which they commonly make.

Therefore, the objectives of this study are to find out whether or not split dictation technique is an effective technique to improve students' listening skill and to find out whether or not there is a significant difference between students who were taught by using split dictation and those who were taught by using a conventional method.

\section{METHODS}

The type of this study belonged to a quasi-experimental design. Based on Montgomery and Douglas (1997, p.1), experimental design is the process of planning a study to meet specified objectives and to answer the research question as clearly and as efficient as possible. As stated by Bhat (2013, p.5) a 
quasi-experimental research design is similar to experimental research but is not exactly that. In this research design, an independent variable is manipulated but the participants of a group are not randomly assigned as per conditions. The independent variable is manipulated before calculating the dependent variable and so, the directionality problem is eliminated.

The subject of this study was the tenth-grade students of SMA N 1 Sukorejo in the academic year 2017/2018. Class X MIA 1 was chosen as the experimental group taught by using split dictation technique, while X MIA 2 was chosen as the control group taught by using conventional method. Each group consisted of 36 students.

The type of data used in this research was quantitative data. As stated by Mertler (2015, p.215) the quantitative data is related to numeral form. The quantitative data of this study were the students' results in a listening test using split dictation technique. It was obtained by giving a pre-test and a posttest to measure students' ability before and after the treatments. Before the tests were conducted, the tryout test must be done in order to find out the validity, reliability, difficulty level, and discriminating power of the test items.

The primary instrument used in this study was a test. As stated by Brown (2004) a test is a method of measuring a person's ability, knowledge, or performance in a given domain. In this study, the writer used an achievement test. Achievement test was a test which had a role to determine whether course objectives had been met and appropriate knowledge and skills acquired- by the end of a period of instruction ( Brown 2004, p.48).

After collecting the data, the researcher analyzed the data by using some method. First, the researcher analyzed the result of pre-test and post-test to get the measure of central tendency (mean). Second, the researcher was calculating the normality of the test. Normality test was used to measure whether the obtained data was normal or not (Basrowi and Soeyono, 2007, p.85). The data were classified into normal when the p-output was higher than 0.05 . In measuring normality test, ShapiroWilk in IBM SPSS $23^{\text {th }}$ version was used. Third, the researcher was calculating the homogeneity of the tests. Homogeneity test was used to measure the obtained data whether it was homogeneous or not. According to Basrowi and Soeyono (2013, p.106), the score is categorized homogeneous when the p-output was higher than the significant difference at 0.05 levels. In measuring homogeneity test, Levine formula in IBM SPSS $23^{\text {th }}$ version was used.

After analyzing the normality and homogeneity, the researcher calculated Paired Samples TTest and Independent Samples T-Test by using IBM SPSS $23^{\text {rd }}$ version in order to find out whether or not the means between the experimental and the control group was statistically significant. This t-test measures the significant difference between the two set of data that gathered. Statistically, the result compares between $\mathrm{t}$-value and the t-table and the significant difference level (2-tailed). When the $\mathrm{t}$ value higher than $\mathrm{t}$-table, and significant difference level (2-tailed) was lower than 0.05 , it could be concluded that $\mathrm{H}_{1}$ is accepted and $\mathrm{H}_{0}$ is denied. It also meant that there was a significant difference between the two data.

\section{FINDINGS AND DISCUSSION}

The result of this research was organized based on the technique of gathering the data

\section{The Test Result}

After observing the whole test results from the pre-test, post-test, and the result of the questionnaire the writer could make a conclusion that students' achievement increased after received the treatment. The result of the whole test can be seen in the table below: 
Table 1 Test Result

\begin{tabular}{|c|c|c|c|c|}
\hline & \multicolumn{2}{|c|}{ Control Group } & \multicolumn{2}{|c|}{$\begin{array}{l}\text { Experimental } \\
\text { Group }\end{array}$} \\
\hline & $\begin{array}{l}\text { Pre- } \\
\text { test }\end{array}$ & $\begin{array}{l}\text { Post- } \\
\text { test }\end{array}$ & $\begin{array}{l}\text { Pre- } \\
\text { test }\end{array}$ & $\begin{array}{l}\text { Post- } \\
\text { test }\end{array}$ \\
\hline $\mathrm{N}$ & 36 & 35 & 36 & 36 \\
\hline $\begin{array}{l}\text { Total } \\
\text { score }\end{array}$ & 2395 & 2795 & 2425 & 2980 \\
\hline Mean & 66,527 & 77,638 & 67,361 & 82,7 \\
\hline
\end{tabular}

In the pre-test, the table shows that mean score of the experimental group is 67,361 , while the mean score of the control group is 66,527 . It could be concluded that there was only a slight difference both experimental and control group before getting treatments.

After getting the treatments, the students' listening achievement of the experimental and control group was increased. It could be seen from the mean score of the two groups. The average score of the experimental group was 82,7 , while the control group average score was 77.638 . The conclusion drawn from the table above was after getting the treatments, the students' listening achievement of the experimental and control group was increased. It could be seen from the mean score of the two groups.

Before calculating the t-test, the researcher used IBM SPSS $23^{\text {rd }}$ version to find out the normality test. This test used the Shapiro-Wilk test with significance level 0,05 . The normality test result of the pre-test and post-test between the experimental and the control group could be seen in the following table:

Table 2 Pre-Test Normality of Experimental and Control Group

\begin{tabular}{lccc}
\hline & \multicolumn{3}{c}{ Shapiro-Wilk } \\
\cline { 2 - 4 } & Statisti & & \\
& $\mathrm{c}$ & $\mathrm{df}$ & $\mathrm{Sig}$. \\
Pretestcontrol & .924 & 36 & .016 \\
$\begin{array}{l}\text { pretestexperi } \\
\text { mental }\end{array}$ & .923 & 36 & .015 \\
\hline
\end{tabular}

\section{a. Lilliefors Significance Correction}

From the calculation of the table above, it could be concluded that the pre-test in this research was normally distributed since the sig value of the two groups were higher than 0.05 . The SapphiroWilk sig (significance) value of the experimental group in the pre-test was 0.015, while, the SapphiroWilk sig value of the control group in the pre-test was 0.016 .

Table 3 Post-Test Normality of Experimental and Control Group

\begin{tabular}{cccc}
\hline & \multicolumn{3}{c}{ Shapiro-Wilk } \\
\cline { 2 - 4 } & Statistic & $\mathrm{df}$ & Sig. \\
Posttestcontrol & .870 & 36 & .013 \\
$\begin{array}{c}\text { Posttestexperime } \\
\text { ntal }\end{array}$ & .935 & 36 & .056 \\
\hline
\end{tabular}

a. Lilliefors Significance Correction 
From the calculation of Table 3, it could be concluded that the post-test in this research was normally distributed since the sig value of the two groups were higher than 0.05 . The Sapphiro-Wilk sig (significance) value of the experimental group in the post-test was 0.056 , while, the Sapphiro-Wilk sig value of the control group in the post-test was 0.013 .

After calculated the normality of the test, the researcher used IBM SPSS $23^{\text {th }}$ version to find out the homogeneity of the pre-test and post-test for both experimental and control group. The homogeneity of the pre-test and post-test of both groups could be seen in the table below

Table 4 Pre-Test Homogeneity of Experimental and Control Group

\begin{tabular}{ccccc}
\hline $\begin{array}{l}\text { Levene } \\
\text { Statistic }\end{array}$ & \multicolumn{1}{l}{ df1 } & \multicolumn{1}{c}{ df2 } & Sig. \\
\hline .046 & 1 & 70 & .831 \\
\hline
\end{tabular}

Based on the calculation of the data above, the Sig value of levene statistics was 0.831 higher than the level of significant (0.05). Thus, it could be concluded that the population between the experimental and control group were homogenous.

Table 5 Post-Test Homogeneity of Experimental and Control Group

\begin{tabular}{cccc}
\hline $\begin{array}{l}\text { Levene } \\
\text { Statistic }\end{array}$ & df1 & df2 & Sig. \\
\hline .172 & 1 & 70 & .680 \\
\hline
\end{tabular}

Based on the calculation of the data above, the Sig value of levene statistics was 0.680 higher than the level of significant (0.05). Since the pre-test and post-test data that have been collected higher than the level of significant (0.05), thus it could be said as the homogeny data. Then, the t-test could be counted.

Then, the researcher calculated t-test in Independent Samples T-Test, the researcher used the IBM SPSS $23^{\text {rd }}$ version to find out whether or not the post-test result between both groups was statistically significant. Results of the computation could be seen in the table below:

Table 6 Post-Test Independent Samples Test

\begin{tabular}{|c|c|c|c|c|c|}
\hline & \multicolumn{2}{|c|}{$\begin{array}{c}\text { Levene's test for } \\
\text { equality of variances }\end{array}$} & \multicolumn{3}{|c|}{$\begin{array}{l}\text { t-test for Equality of } \\
\text { Means }\end{array}$} \\
\hline & $\mathrm{F}$ & Sig & $\mathrm{t}$ & $\mathrm{df}$ & $\begin{array}{l}\text { Sig (2- } \\
\text { tailed) }\end{array}$ \\
\hline $\begin{array}{l}\text { Result of equality post-test } \\
\text { variances assumed }\end{array}$ & .172 & .680 & 4.189 & 70 & .000 \\
\hline $\begin{array}{l}\text { Equality post-test variances not } \\
\text { assumed }\end{array}$ & & & 4.189 & 67.668 & .000 \\
\hline
\end{tabular}


Since the $t_{\text {value }}(4.189)$ was higher than $t_{\text {table }}(1.994)$ for $\alpha=5 \%$ and $\mathrm{df}=70$, and the score of the sig ( 2 tailed) was 0.000 lower than 0.05 , it could be concluded that $\mathrm{H}_{1}$ is accepted and $\mathrm{H}_{0}$ is denied. In this research, $\mathrm{H}_{1}$ means that the use of split dictation technique was effective to improve students' listening skill, while $\mathrm{H}_{0}$ means the use of split dictation technique was not effective to improve students' listening skill.

\section{Discussion}

After observing the whole test results from the pre-test, post-test, and the result of the questionnaire the writer could make a conclusion that students' achievement increased after received the treatment. The result of the whole test can be seen in the figure below:

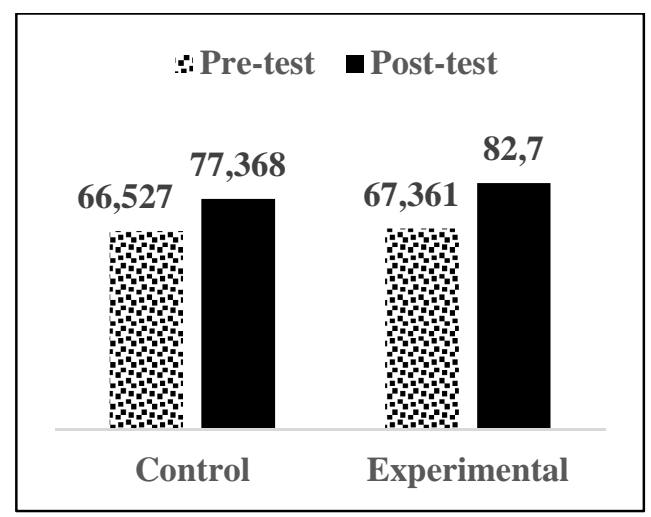

Figure 1 pre-test and post-test results

Based on the chart above, the average score of the experimental group was 67.3 and the control group was 66,5. After both of groups received different treatments, the average score of the experimental group increased 15.4 points to be 82.7 whereas the control group increases only 10.8 points to be 77.3. This indicated that after getting the treatments, the experimental group got greater improvement than the control group. From the calculation above, it could be concluded that after received treatments by using split dictation technique, the students' achievement on the listening test was increased. As a result, the use of split dictation successfully improved the students' achievement in the listening test.

The result was also proved by the computation of t-test which the score of the sig ( 2 tailed) was 0.000 lower than 0.05 . it was also supported by the result of the t-test. The result showed that $t_{\text {value }}$ was 4.189 while the $t_{\text {table }}$ was 1.994 . It showed that the $t$-value $>$ the t-table. In conclusion, there was a significant difference between the students' listening test achievement. This finding revealed the previous studies done by (Kiany, 2012; Aini, 2015; Dwinalida, 2012) that the use of dictation technique is effective to improve the students' listening skill. In conclusion, the writer concluded that split dictation technique really gave a good contribution to improve students' listening skill, besides it also changed the students' learning behavior to be better. The students have gained both confidence and skills in the listening activity. Another valuable thing that the students learn from split dictation was that the technique helped them sharpen their handwriting and spelling.

\section{CONCLUSION}

The objectives of this study are to find out whether or not split dictation technique is an effective technique to improve students' listening skill and to find out whether or not there is a significant difference between students who were taught by using split dictation and those who were taught by 
using a conventional method. From the data obtained in this research, there are some points which could be taken as a conclusion.

Firstly, the use of split dictation technique is effective to improve students' listening skill. It is proven by the improvement of the students' score in the pre-test and the post-test. The result showed that the implementation of split dictation technique could improve students' listening skill. The mean of students' score in experimental class improved from pre-test to post-test, from 67,361 to 82,7 while the control group improved from 66,527 to 77,638. After both of groups received different treatments, the average score of the experimental group increased 15.4 points to be 82.7 while the control group increased only 10.8 points to be 77.6 . This indicated that after getting the treatments, the experimental group got higher improvement than the control group.

Secondly, there is a significant improvement of the students' achievement after they had received the treatments by using split dictation. It is showed in the calculation of the t-test by using SPSS program. The result showed that the score of the t-value (4.189) was higher than the t-table (1.994) for $\alpha=5 \%$ and $\mathrm{df}=70$; $\mathrm{Sig}$ ( 2 tailed) value 0.000 was lower than 0.05 . Since the t-value was higher than the t-table, and Sig ( 2 tailed) value was lower than 0.05 , it could be stated that there was a significant difference between the students' who were taught by using split dictation and those who were taught by using a conventional method.

\section{SUGGESTION}

Based on the conclusion of the research, there are some suggestions that could be taken to enhance students' listening skill.

Theoretically, the finding of this study is expected to develop further research. For next researchers who are interested in the same field are recommended to implement the actions in a longer period of time to get more maximum results so that the improvement will be more significantly seen as a literature when they have similar research. The researcher also hopes that the next researcher can explore other kinds of dictation technique as a new teaching strategy to improve students' listening skill.

Practically, the result of the study is expected to help students to be more active in the learning process. They should improve their understanding and achievement in learning English especially in listening. They can use audio passage, music, article, or video as a medium to help them understand the English language. They also should study harder and practice English they have learnt.

Pedagogically, it is hoped that the result of this study will be useful for English teacher. The English teacher should prepare various and different media for teaching and learning process to avoid students' boredom. It is important for the teacher to maintain students' focuses which play important role in the teaching learning process. Once students keep their focus they will be interested, and after they get interested in the teaching and learning process they will be better at the class in every classroom activities.

\section{REFERENCES}

Arikunto. (2002). Metodologi Penelitian Suatu Pendekatan Proposal. Jakarta: PT Rineka Cipta.

Basrowi, \& Soeyono. (2007). Metode Analisis Data Sosial. Kediri: CV Jenggala Pustaka Utama Cangara Hafied.

Bhat. (2013). Experimental Design. Experimental Research Design, 13.

Brown. (2004). Research Methods for Applied Linguistics. San Fransisco: State University Press.

Burns. (2010). Doing Action Research in Language Teaching : A Guide for Practitioners. The Canadian Journal of Action Research.

Davis, P., \& Rinvolucri, M. (1998). Dictation : New methods, new possibilites. Cambridge: Cambridge University Press. 
Kidd, R. (1992). Teaching ESL Students through Dictation. Toronto: TESL Canada.

Montmogery, \& Douglas. (1997). Design and Analysis of Experiments. Design and Analysis of Experiments, 1.

Mertler. (2015). Introduction to educational research. 215.

McErlain. (1999). The Nature of Listening: The need for listening in English for Academic Purposes. Quoted on August 2018, from www.aelfe.org/documents/text1-McErlain.pdf.

Montalvan. (2006). Dictation Updated: Guidelines for Teacher-Training Workshops. Quoted on August 2018, from http://exchanges.state.gov/education/engteaching/dictation.html.

Nunan, D. (2001). Listening in Language Learning. Teaching English as a Second or Foreign Language, 23. 